\title{
Studying and Teaching History in the Aftermath of 1968: A Memoir
}

\author{
Hans-Jürgen Grabbe
}

\section{(2) OpenEdition \\ Journals}

Electronic version

URL: https://journals.openedition.org/ejas/3403

DOI: $10.4000 /$ ejas.3403

ISSN: 1991-9336

Publisher

European Association for American Studies

\section{Electronic reference}

Hans-Jürgen Grabbe, "Studying and Teaching History in the Aftermath of 1968: A Memoir", European journal of American studies [Online], 3-2 | 2008, document 7, Online since 30 November 2008,

connection on 08 July 2021. URL: http://journals.openedition.org/ejas/3403 ; DOI: https://doi.org/

10.4000/ejas.3403

This text was automatically generated on 8 July 2021 .

Creative Commons License 


\title{
Studying and Teaching History in the Aftermath of 1968: A Memoir
}

\author{
Hans-Jürgen Grabbe
}

\section{Introduction}

1 Politics has been a concern of mine since I was about fourteen years old, and since my American Field Service exchange in 1965-1966 I have been following world events as closely as possible. However, in the fall of 1967 I became a soldier in the West German Army and was cut off from much of the information that I had so eagerly digested before. Of course, I knew that the government of the Grand Coalition was in power in Bonn and that my hero Willy Brandt had become foreign minister. I had high hopes for East-West reconciliation. Vietnam had been on my mind since 1965, but in 1967 it was not at the forefront of my interests. The unrest in Poland in March 1968 also largely escaped my attention, as did the events of May 1968 in France.

But when Warsaw Pact forces invaded Czechoslovakia on the night of August 20-21, my battalion was moved to a marshalling area in the forests of northern Hesse. As I understand today, we were part of a NATO force protecting the so-called Fulda Gap through which an anticipated Soviet and East German move into southern Germany had to come. I knew nothing about that at the time, and after weeks in the sticks my only concern was a hot bath, which I eventually enjoyed at a nearby hospital.

My second encounter with the forces unleashed in 1968 came in October. I had been promoted to the rank of ensign and was an officer of the guard at Field Marshall Rommel Barracks in Augustdorf near the Westphalian city of Bielefeld. One day, I was told by my superiors to draw up emergency plans in case rebellious students from Bielefeld University attempted to force an entry into the Augustdorf compound.

Bielefeld at that time was still a university in statu nascendi. Niklas Luhmann, a sociologist, became the first professorial appointee on October 1, 1968, and the university received its charter roughly a year later. But there was student unrest everywhere in West Germany and West Berlin, and some of the repercussions had reached this Westphalian backwater.

2. Entering Academia 
In March 1969 I was discharged as second lieutenant and decided that I would begin studying history, political science, and English at the University of Hamburg the following summer. My ambition was to become a secondary school teacher and for that two or three fields of study were necessary. Since Hamburg at that time had many famous scholars on its faculty, I also wanted to pursue a broad studium generale.

This brought me into the Auditorium Maximum, with a seating capacity of 1700, where Reinhard Tausch, chair of educational philosophy, held an introductory lecture. About halfway through, and much to my bewilderment, he encouraged us to turn to our neighbors right and left and begin two minutes of what he called "gegenseitige Wertschätzung" (mutual appreciation). The idea was that we should smile at one another and engage in small talk. Later I learned that this was an exercise in group dynamics, but since I did not know that at the time, I quietly left.

7 To form groups, to study in groups, to present findings as a group was the order of the day. I did not care for this because I had spent the last two years of my life in a group and wanted to be left alone. I did not even apply for a room in a dormitory. It seemed that everybody in education, psychology, and the social sciences and most junior faculty in all other fields were influenced by Bruce Tuckman's concept of group dynamics and its five steps of forming, storming, norming, performing, and informing. ${ }^{1}$

My first seminar in political science, in the summer semester of 1970, was an introduction to comparative politics. Students were to compare the German, British, and American systems of government. However, we only spent about half of the thirteen sessions on questions relevant to the topic. In the first session a young woman rose and suggested a study program focusing on group dynamics. She also said, however, that we were probably not ready yet for that ambitious project and so should begin to enquire about ourselves by reading Anna Freud. Since this proposal was voted down, it took me some time to realize that she was referring to Freud's Psychoanalysis for Teachers and Parents which had been put out in a pirated edition by a publisher called "Rotverlag" (Red Publishing House) in 1970. ${ }^{2}$

The four lectures that comprise Anna Freud's book were originally presented to the teachers of the Children's Center in Vienna. They were on "Infantile Amnesia and the Oedipus Complex," "The Infantile Instinct-Life," "The Latency Period," and "The Relation between Psychoanalysis and Pedagogy." In the latter, Anna Freud recommended that teachers undergo psychoanalysis before educating children, and perhaps my fellow student of political science wished to recommend that we analyze ourselves before embarking on further study. Individual and collective analyses were on everyone's lips in those days. In 1967, psychologists Alexander and Margarete Mitscherlich had published their seminal work Die Unfähigkeit zu trauern: Grundlagen kollektiven Verhaltens (The Inability to Mourn: Principles of Collective Behavior) which was on the bestseller lists for more than a year and sold over a hundred thousand copies in cloth. $^{3}$ The Mitscherlichs claimed that in the Adenauer era, from 1949 to 1963, West Germans had collectively suppressed memories of their Nazi past and had failed to acknowledge the crimes committed in the name of National Socialism. This was also one of the major reproaches brought against the so-called establishment during the early stages of the student movement.

But let us move back to my political science seminar. I was part of a group that was to look into the British parliamentary system. Since there was no guidance from the lecturer, we counted on the senior member of the group to lead the way. He told me to 
go to the library and to check out a little red book from an East German publisher. This was by a "Collective of Authors under the Direction of Günther Großer" and bore the title: Der wissenschaftliche Kommunismus-Bestandteil des Marxismus-Leninismus: Einführung in den Gegenstand und die Geschichte des wissenschaftlichen Kommunismus ("Scientific Communism-A Component of Marxism-Leninism: Introduction to the Subject and to the History of Scientific Communism"). ${ }^{4}$ I was bewildered, since I had never thought of socialism as scientific in any way. As a consequence, the performing and informing parts of our group work were a total disaster. I did not accept what I had read, which in short could be subsumed in a motto from a banner shown in East Berlin in the late 1960s (and now in the possession of the German Historical Museum): "Marxism-Leninismn is correct, because it is true." ${ }^{5}$ As a consequence, I kept quiet. The lecturer then turned the plenary session into a tribunal and asked our fellow students whether we deserved the coveted "Schein" or certificate of achievement. It was at that moment that I quit studying political science.

3. History and Emancipation: The Influence of Habermas

11 The situation in the history department was different, but the insistence on group work was similar. Horst-Eberhard Richter, a psychiatrist and a leading figure in the peace movement, had written a book entitled Die Gruppe-Hoffnung auf einen neuen Weg, sich selbst und andere zu befreien: Psychoanalyse in Kooperation mit Gruppeninitiativen ("The Group-Hope for a New Way to Liberate Oneself and Others: Psychoanalysis in Cooperation with Group Initiatives"). It was a best-selling book in $1972 .{ }^{6}$ Richter used to park his Jaguar XJ in a side street near the Auditorium Maximum when he came to lecture. For him, the traditional nuclear family was a "defenseless and willing tool of overpowering societal influences." In contrast, the group might cure or help avoid inhibitions that prevented us from embarking on an emancipatory course. ${ }^{7}$

Emancipation was the key word of 1968 and beyond. As a fledgling history student I was first acquainted with it, as were many others, through the writings of Jürgen Habermas. One work in particular had a major impact on German intellectual discourse in 1968 and the years that followed. This was "Erkenntnis und Interesse", his 1965 inaugural lecture at the University of Frankfurt upon Main, published in 1968 as part of a collection with the same title. It appeared in America as Knowledge and Human Interests in $1971 .^{8}$ In the United States and in Britain the impact was less pronounced. Knowledge and Human Interest finishes forty-ninth among the fifty twentieth-century works most cited in the Arts \& Humanities Citation Index between 1976 and $1983 .{ }^{9}$ The front runners were Thomas Kuhn, The Structure of Scientific Revolutions, James Joyce, Ulysses, and Northrop Frye, Anatomy of Criticism. Wittgenstein, Chomsky, Foucault, Derrida, Roland Barthes, Heidegger and Ernst Robert Curtius occupied slots four to ten. In "Erkenntnis und Interesse", Habermas develops a theory of "knowledge-constitutive interests" that are tied both to "the natural history of the human species" and to "the imperatives of the socio-cultural form of life," but are not reducible to them. There are three knowledge-constitutive interests. The first is the "technical interest," the "anthropologically deep-seated interest" we have in the prediction and control of the natural environment. Second, there is the equally deep-seated "practical interest" in securing and expanding possibilities of mutual and self-understanding in the conduct of life. Finally, there is the "emancipatory interest" in overcoming dogmatism, compulsion, and domination. ${ }^{10}$ 
13 It was only recently that I read James F. Bohman's appraisal that "the status of the emancipatory interest [. . .] was problematic from the start." Bohman is Danforth Professor of Political Philosophy, Philosophy of Social Science, and 19th Century and Contemporary German Philosophy at St. Louis University, and he writes in the Stanford Encyclopedia of Philsosophy: "The interest in emancipation does not clearly correspond to a specific science or form of institutionalized inquiry. Although Freudian psychology and Marxist social theory have such an interest, much if not most psychological and sociological inquiry does not have explicitly emancipatory aims, but rather is driven by interests in prediction and social understanding. Nor was it clear that psychoanalysis provided an apt model of liberatory reflection , [since,] as critics pointed out, [. . .] the asymmetries between patient and analyst could not represent the proper intersubjective form for emancipation. These deficits posed a challenge for Habermas that would guide a decades-long search for the normative and empirical basis of critique." 11 Habermas eventually overcame this challenge, but I, my fellow students, my teachers and just about everybody whom I knew at the time did not. In his book Legitimationsprobleme im Spätkapitalismus, translated in 1975 as Legitimation Crisis, ${ }^{12}$ Habermas argued not only that the demands of advanced capitalism restrict the scope and significance of democracy, but also that the state is "crisis-ridden" and unable to solve structural problems of unemployment, economic growth, and environmental destruction. Contrary to "formal" democracy understood as majority rule, Habermas proposes "substantive democracy," which emphasizes the "genuine participation of citizens in political will formation." 13 What Habermas had in mind may well have been the civic culture as described by Almond and Verba in $1963 .{ }^{14}$ But it translated differently into the history taught at my department in Hamburg.

The scion of Hamburg historians was Fritz Fischer who, in 1967, had published a massive tome on Der Griff nach der Weltmacht (literally: "Seizing World Power"), to be followed eight years later by his Krieg der Illusionen (War of Illusions). ${ }^{15}$ Fischer was aloof from the intellectual trends of the times but commanded great respect among students because he had dared to challenge the conventional wisdom that the great powers of Europe had somehow become mixed up in a crisis that brought about the First World War. Instead, Fischer insisted that German imperialists craving the proverbial place in the sun and overall dominance were to blame. The "Fischer thesis" was perceived as an emancipatory act because it put most of the older generation of historians on the defensive and opened the door for the kind of purgatory experience that the Mitscherlichs demanded, drawing a line from Luther to Bismarck and Hitler, thus discrediting once and for all the German nation state.

In 1974, one of Fischer's students, Immanuel Geiss, and Rainer Tamchina, my immediate predecessor as assistant professor of overseas history at the history department of the University of Hamburg, published a two-volume collection of essays entitled "Views of the Future Study of History" (Ansichten einer künftigen Geschichtswissenschaft). The first volume dealt with criticism, theory, and methodology, the second offered an example of the new historiography that the authors proposed. Taking stock of the historiography of the late 1960s, Geiss diagnosed restoration, stagnation, and productive crisis. He contrasted a historiographic orthodoxy of "heralds and apologists" of the Wilhelmine empire and Hitler's Third Reich with a new generation of historians who matured in the student movement of the late 1960s and who increasingly turned away from the "conservative CDU/CSU." This generation, he 
insisted, had been willing to learn the historic lessons of 1917 and 1945, of the "unmistakable crisis of capitalism," of the dissolution of colonial imperialism and-somewhat tautologically-of "the definitive perdition" of the Third Reich and fascism. ${ }^{16}$ Students and the general public were tired of history and had even lost history because of the sterility of an older generation of practitioners whose dated historicism dealt only with the ups and downs of the German nation state. ${ }^{17}$

The tasks at hand were to cease production of narratives that legitimized rule and to unmask myths and legends. The historiography of the future should use the "historic dimension" for a better understanding of the present and as a contribution towards a rational and humane design for the future. Scientific work was legitimate only if it contributed to the political enlightenment of society. ${ }^{18}$ In the proseminar "Introduction to the Study of Modern History" which I attended in the summer semester of 1969, we were advised to always look for "handfeste Interessen"-the tangible, material interest that allegedly stood behind every historical phenomenon.

\section{After 1968: The End of Emancipation}

The years after 1968 were the halcyon days of the concept of Geschichte als Historische Sozialwissenschaft (History as Historical Social Science), popularized by Hans-Ulrich Wehler in a slim Suhrkamp pocket book of $1973 .{ }^{19}$ Sociology, economics, and psychoanalysis were the new ingredients that, according to Wehler, should strengthen the social scientific credentials of history. The faculty members from the Hamburg history department in their Views of the Future Study of History proposed "Gesellschaftsgeschichte", history of society, as the new paradigm, with Max Weber as one of the patron saints. But they also insisted that history become a "critical" discipline, embracing the critical theory of Habermas and the Frankfurt School. ${ }^{20}$

Where would all this lead in practice? Volume two of Views of the Future Study of History provides an answer. It is entitled "Revolution: A Historical Longitudinal Section." Following a brief introduction on "Revolution in World History," individual authors explore the transition from the Roman republic to the principate under the subtitle "A Revolution?," ask whether the Ciompi Revolt (a 1378 uprising in Florence) constituted a conflict between estates or was indeed a revolution; other authors deal with the French Revolution, the Russian Revolution, the abortive German revolution of 1918-1919, and industrialization and revolution (with Japan and China as case studies). The penultimate chapters are devoted to national liberation and social change in Latin America and Africa. Taken on its own, it is a stimulating book. However, in the mid-1970s the Hamburg history department modified its curriculum to make room for so-called project studies. The first project introduced was, not surprisingly, Revolution, a series of courses that built on one another and that, if one enrolled in them, would have constituted about fifty percent of the total required workload in the master's program.

What was my answer as a student of history when faced with these developments? It was to turn to the study of the United States. Whereas an average of well over one hundred students flocked to the courses of the new historians, most of whom parochially focused on themes of German history, only five co-students attended my first U.S. History seminar on "The Pacific as a Sphere of Interest of European and American Powers." We looked at charts of the Juan da Fuca Strait (separating Vancouver Island and the north coast of Washington state), read US-American, British, and Spanish source texts, and marveled at the exploits of His Majesty's Company of 
Merchant Adventurers Trading into Hudson's Bay. And an adventure it was. I have never tired of it since.

In the winter semester of 1970, the traditional intermediary examination was abolished and courses were no longer graded. One passed, or one failed; grading was considered oppressive. I must admit, I rather liked this aspect of the new system. However, in 1977, when I taught my first seminar as an Assistant Professor, I found it infiltrated by about a dozen members of the Marxist-Reichist Initiative. Wilhelm Reich was a psychotherapist who believed in primordial cosmic energy and built a machine called an Orgon Accumulator that would boost man's orgiastic potency. The Marxist-Reichists did not insist on having an orgy in class, but they did insist that I had no authority over proceedings, that the students were completely autonomous, and that I might only advise them when specifically asked to do so. The course was on the Federal Republic of Germany in the 1950s, at a time when the notorious Hans Globke was State Secretary in the Chancellor's Office. In their presentation, the Marxist-Reichists insisted on calling him Hans Maria von Globke. I must admit, I was utterly helpless and only rose to their challenge when the group taunted and ostracized the daughter of the then mayor of Hamburg, a Social Democrat, who, in their perverted view, was a betrayer of the working class and a crypto-fascist.

What had gone wrong? Between 1968 and 1971, ideas of emancipation had slowly but steadily given way to a strict class consciousness among a vociferous, well-organized and well-funded minority of students. For them, the emancipatory interest was identical with the interest of a mythical working class. In 1969, the Marxist kernel of the SDS, the Socialist German Student Federation, left this organization and founded an Association of Marxist Students, renamed the Marxist Student Federation Spartacus (MSB Spartacus) in 1971. The MSB Spartacus soon became the strongest faction in the Hamburg student parliament. It was affiliated with the German Communist Party and funded by the Socialist Unity Party of the German Democratic Republic. Equally orthodox, but more sectarian-one might say almost Scientology-like-was the Communist Federation of West Germany (Kommunistischer Bund Westdeutschland) whose members had to deliver up ten percent of their earnings, gifts, and inheritances. Prominent figures like Horst-Eberhard Richter no longer spoke to students in Hamburg. Instead, the "student Bernd Rabehl," as he was advertised (then in his twenty-third semester), a friend and comrade-in-arms of Rudi Dutschke, lectured about the problems of class struggle. Today, Rabehl lectures at rallies of the neo-Nazi party NPD.

Less orthodox students like myself briefly flirted with the Maoists who were perceived as less orthodox and more intelligent. I still possess a copy of the Words of Chairman Mao, purchased in 1969. For a time, I subscribed to the Peking Review, but this was curiosity mixed with a desire to appear different. I also sported a mustache and smoked a pipe. Another group, the Maoist Communist Party of Germany/Marxist-Leninist, whose seemingly limitless funds (rumoured to come from North Korea) provided a stream of quality posters and pamphlets, unmasked me as an enemy of the people on a wall newspaper in the lobby of the so-called Philosophy Tower that housed the humanities. At least I was spared the experience of a mock execution. There were incidents in the 1970s when students would violently enter an office, put a plastic sack over the occupant's head, open the window and push him or her on to the window sill. The history department, I might add, is on the ninth floor of a thirteen-story building. One 
day, students got hold of a master key, opened all the doors and lifted them from the hinges. Hapless professors stood on the thresholds of their offices, arms askance, trying to protect their files. In vain, of course. This ended the community of Hamburg history teachers and students for about two decades. After that, emancipation, as far as I was concerned, was a dead letter, and I decided to become my own man.

5. Conclusion

I have always had a soft spot for Leopold von Ranke's often misunderstood guideline to the historian found in the preface to his first book, the Histories of the Latin and Teutonic Peoples. Ranke wrote that his work did not aspire to the "high offices" that had previously (in the Enlightenment) been assigned to history: Historiography does not have "the duty to judge the past, nor to instruct contemporaries with an eye to the future, but rather merely to show how it actually was." 21 Another sentence from the same source looms large: The intent of the historian is dependent on his opinion or mindset. ${ }^{22}$ This is not a paraphrase of Habermas' "erkenntnisleitendendes Interesse" because the emancipatory urge is lacking. I see it more as an admonition to be cautious and aware that one's intellectual, cultural, and ethnic roots have a bearing on one's research and subsequent ratiocinations.

As a historian of the United States, I have tended to shy away from what Max Weber called "Werturteile" (value judgments) - difficult as this may have been in the era of George W. Bush-and have tried my best to explain American history and society to students and the general public in my own country without taking sides in intraAmerican conflicts. In a way, I have become a disciple of Hans-Georg Gadamer's philosophical hermeneutics by insisting "on the limited role of method and the priority of understanding as a dialogic, practical, situated activity." ${ }^{23}$ Looking back on over thirty years as a professional historian, I can say that this is the lesson that 1968 and its aftermath taught me.

\section{NOTES}

1. Bruce W. Tuckman, "Developmental Sequence in Small Groups," Psychological Bulletin 63 (1965): 384-99.

2. Anna Freud, Psychoanalysis for Teachers and Parents, trans. Barbara Low (Boston: Beacon Press, 1935; rpt. [no place]: Rotverlag, [ca. 1970]).

3. Alexander und Margarete Mitscherlich, Die Unfähigkeit zu trauern: Grundlagen kollektiven Verhaltens (München: Piper, 1967); The Inability to Mourn: Principles of Collective Behavior (New York: Grove Press, 1975).

4. Autorenkollektiv unter Leitung von Günther Großer, Der wissenschaftliche Kommunismus-Bestandteil des MarxismusLeninismus: Einführung in den Gegenstand und die Geschichte des wissenschaftlichen Kommunismus (Berlin: Deutscher Verlag der Wissenschaften, 1972). 
5. “Der Marxismus-Leninismus ist richtig, weil er wahr ist.“

6. Reinbek bei Hamburg: Rowohlt,1972.

7. From the preface of Die Gruppe.

8. Erkenntnis und Interesse (Frankfurt am Main: Suhrkamp, 1968);

Knowledge and Human Interests, trans. J. J. Shapiro (Boston: Beacon

Press, 1971).

9. <http://home.comcast.net/ antaylor1/fiftymostcited.html>

10. James Bohman and William Rehg, "Habermas," Stanford Encyclopedia of Philosophy, 17 May 2007. See <http://plato.stanford.edu/entries/

habermas>.

11. Ibid.

12. Jürgen Habermas, Legitimationsprobleme im Spätkapitalismus

(Frankfurt am Main: Suhrkamp, 1973); Legitimation Crisis, trans. by

Thomas McCarthy (Boston: Beacon Press, 1975).

13. James Bohman, "Critical Theory," Stanford Encyclopedia of

Philosophy, 8 March 2005. See <http://plato.stanford.edu/entries/critical-

theory/>.

14. Gabriel Almond and Sidney Verba, The Civic Culture: Political

Attitudes and Democracy in Five Nations (Princeton, NJ: Princeton Univ.

Press, 1963).

15. Fritz Fischer, Der Griff nach der Weltmacht (Düsseldorf: Droste, 1961)

[Germany's Aims in the First World War (London: Chatto \& Windus,

1967)]; idem, Krieg der Illusionen (Düsseldorf: Droste, 1969) [War of

Illusions: German Policies from 1911 to 1914 (London: Chatto and

Windus, 1975)].

16. Imanuel Geiss and Rainer Tamchina, eds., Ansichten einer künftigen

Geschichtswissenschaft, 2 vols. (München: Hanser, 1974) I: 19-20.

17. Ibid., 21.

18. Ibid., 23.

19. Hans-Ulrich Wehler, Geschichte als Historische Sozialwissenschaft

(Frankfurt am Main: Suhrkamp, 1973).

20. Geiss and Tamchina, 8.

21. Leopold von Ranke, Preface to Geschichten der romanischen und germanischen Völker (1824): “Man hat der Historie das Amt, die Vergangenheit zu richten, die Mitwelt zum Nutzen zukünftiger Jahre zu belehren, beigemessen: so hoher Aemter unterwindet sich gegenwärtiger Versuch nicht: er will blos zeigen, wie es eigentlich gewesen."

22. "Die Absicht eines Historikers hängt von seiner Ansicht ab." 23. Jeff Malpas, "Hans-Georg Gadamer," Stanford Encyclopedia of Philosophy, 3 March 2003 (revised 1 August 2005). See <http:// plato.stanford.edu/entries/gadamer/>. 


\section{AUTHOR}

HANS-JÜRGEN GRABBE

Hans-Jürgen Grabbe, Zentrum für USA-Studien, Martin-Luther-Universität HalleWittenberg. 